\title{
DEVELOPMENT OF SOMATOSTATIN-LIKE IMMUNOREACTIVITY IN EMBRYONIC SYMPATHETIC GANGLIA ${ }^{1}$
}

\author{
GERALD D. MAXWELL, ${ }^{2}$ PAMELA D. SIETZ, AND PAUL H. CHENARD \\ Department of Analomy, Universily of Connecticut Health Center, Farmington, Connecticut 06032
}

Received July 18, 1983; Revised September 12, 1983; Accepted September 12, 1983

\begin{abstract}
Neural crest cells are the embryonic progenitors of several adult cell types, including some neurons that contain the neuroactive peptide somatostatin. To begin to understand the control of peptide expression during neuronal ontogeny, we have investigated the development of somatostatin-like immunoreactivity (SLI) in embryonic quail paravertebral sympathetic ganglia in vivo. SLI was identified by immunohistochemistry in paraformaldehyde-fixed cryostat sections from the trunk region of quail embryos. SLI was first observed in the cells of the primary sympathetic trunks at stage 18 (Zacchei, A. M. (1961) Arch. Ital. Anat. Embriol. 66: 36-62), which corresponds to embryonic day 4 (E4). The primary sympathetic trunks are the sites of the initial aggregation of neural crest cells to form the sympathetic ganglia. The SLI in these cells was located in the cytoplasm and was absent from the nucleus. SLI persisted in subsequent developmental stages as formation of the definitive sympathetic ganglia occurred. At stage 23 (E7), when the lumbosacral paravertebral sympathetic ganglia have reached their definitive location, some cells in the ganglia contained SLI, and they were often located adjacent to one another. During the later stages of embryogenesis, sympathetic ganglia can be dissected from the embryo and the SLI content determined by radioimmunoassay. The amount of SLI is several-fold higher in ganglia removed at stage 23-24 (E7-8) than in ganglia removed at stage 26-27 (E9-10) or stage 31-32 (E13-14). This decline in SLI content reflects an absolute decrease per ganglion and is not solely due to the growth of tissue devoid of SLI. Our results indicate that the appearance of SLI is an early event in the development of some sympathetic neurons in vivo and that the SLI content of sympathetic ganglia decreases significantly during later stages of embryonic development when other maturational events are occurring in these ganglia.
\end{abstract}

Several neuroactive peptides, including those identical or closely related to substance $P$, somatostatin, vasoactive intestinal polypeptide (VIP), and the enkephalins, have been detected in neurons of neural crest origin in several species (Hökfelt et al., 1980). The embryonic neural crest gives rise to several adult cell types, including the neurons of the sympathetic, parasympathetic, enteric, and most sensory ganglia (Weston, 1970; Noden,

\footnotetext{
${ }^{1}$ We thank Dr. Y. Grimm-Jørgensen for advice on radioimmunoassay techniques, for helpful discussions, and for the use of equipment. We thank Dr. P. Levitt for advice on frozen section techniques. We also thank Drs. S. J. Cooperstein, S. J. Potashner, and B. Shur for their comments, Dr. R. Kosher for the use of equipment, and F. Napolitano for typing the manuscript. This work was supported by Grant NS 16115 and a Research Career Development Award from the National Institutes of Health and Basil O'Connor Starter Grant 5-289 from the March of Dimes Birth Defects Foundation to G. D. M. A portion of this work was presented at the 13th Annual Meeting of the Society for Neuroscience (Chenard and Maxwell, 1983).

${ }^{2}$ To whom correspondence should be directed.
}

1978; Le Douarin, 1980). Substance P and somatostatinlike immunoreactivity (SLI) have been demonstrated in some sensory ganglion neurons; substance P, VIP, and the enkephalins in some enteric ganglion neurons; the enkephalins in cells of the adrenal medulla; and SLI and VIP in some sympathetic ganglion neurons (Hökfelt et al., 1980; Fontaine-Perus et al., 1982). In several cases these peptides coexist with a nonpeptide neurotransmitter in the same cell (Hökfelt et al., 1980). For example, some sympathetic neurons contain both catecholamines and SLI (Hökfelt et al., 1977).

Although the existence of neuroactive peptides in particular neuron populations is relatively well documented, our knowledge of the control of neuroactive peptide presence during development is limited. In the developing enteric ganglia of the embryonic chicken, the appearance of substance P-, VIP-, and met-enkephalin-like immunoreactivity has been examined by immunocytochemistry (Fontaine-Perus et al., 1981; Saffrey et al., 1982). All three peptides were first detected at embryonic 
days 10-11 (F10-11). This is a few days after acetylcholine and 5-hydroxytryptamine-containing intrinsic neurons of the gut first appear (Smith et al., 1977, Epstein et al., 1980). One interesting finding is that peptide immunoreactive cell bodies are more numerous in the enteric ganglia of embryonic and young chickens than adults. In addition, when gut tissue from E10-11 embryos is removed from the embryonic environment to an in vivo tissue culture system on a chick chorioallantoic membrane for 10 days, the number of VIP-and substance $\mathrm{P}$-immunoreactive cell bodies is greater than that seen at 21 days of development in the normal animal in vivo (Fontaine-Perus et al., 1981). One possible explanation for these results is that the transport of peptides from the cell bodies to terminals increases during development in vivo. This would reduce the peptide content in the cell bodies and thus decrease the number of peptide-containing cell bodies detectable by immunocytochemistry later in development. Culture of the gut tissue on the chorioallantoic membrane may restrict the growth of cellular processes and terminals, thereby retaining detectable peptide-containing cell bodies. A second, more interesting, possibility is that the actual number of peptidergic neurons is regulated by environmental influences that are supplied by the embryo and which change during development. Growth of the gut tissue on the chorioallantoic membrane would be free of these influences, allowing more peptidergic neurons to be present than are normally seen in vivo.

Although such environmental cues have not yet been directly identified in embryos, recent work has identified several influences that appear to regulate peptide expression in developmentally older neurons and cells of the adrenal gland. This work may be relevant to an understanding of the control of neuronal peptide content during embryogenesis. One such influence is the development of synaptic activity. When adult rat adrenal glands are denervated, they exhibit large increases in enkephalin-containing peptides (Lewis et al., 1981). In adult rat superior cervical ganglia in vivo, substance $\mathrm{P}$ content increases when preganglionic fibers are cut or when impulse activity is blocked (Kessler and Black, 1982). Similarly, substance P and SLI content increase when neonatal rat superior cervical ganglia are grown in vitro, and this increase is prevented by the presence of depolarizing agents (Kessler et al., 1981, 1983a). These observations on the effect of preganglionic activity on the peptide content of the adrenal gland and superior cervical ganglia are consistent with the results on peptidergic cells in avian enteric ganglia, cited above, in a model in which the development of preganglionic innervation and subsequent synaptic activity act to depress peptide expression in the cells which receive innervation.

In addition to the possible role of preganglionic innervation on peptide content, the pattern of postganglionic innervation by sympathetic neurons has been suggested to be relevant to their peptide content (Lundberg et al., 1982). Other influences not requiring cell contact also have been demonstrated to alter the peptide content of neurons. Medium conditioned by non-neuronal cells has been reported to alter qualitatively the type of peptide contained in populations of sensory neurons in culture
(Mudge, 1981), and nerve growth factor (NGF) can elevate substance $P$ and SLI content in rat dorsal root sensory ganglia in vivo (Kessler and Black, 1980, 1981; Otten et al., 1980).

In the present work we have examined the expression of SLI in embryonic quail paravertebral sympathetic ganglia in vivo. These experiments addressed the questions of when SLI can be detected, in what cell populations it is found, and what quantitative changes occur in SLI content during embryogenesis. These experiments are a first step toward understanding how peptide content is regulated during embryonic development and what functional role such neuroactive peptides may play in development.

\section{Materials and Methods}

Embryos. Fertilized Japanese quail eggs (Coturnix coturnix) were purchased from the Nutritional Sciences Department at the University of Connecticut and incubated at $38^{\circ} \mathrm{C}$ in a humidified forced draft incubator (Humidaire Incubator Co.). The developmental stage of the embryos was determined according to the method of Zacchei (1961).

Immunohistochemistry. The location of SLI was determined by the indirect immunofluorescence technique on fixed frozen sections. Embryos stage 19 or older were perfused through the heart with $4 \%$ paraformaldehyde in $0.1 \mathrm{M}$ phosphate buffer, $\mathrm{pH} 7.4$, and then fixed further by immersion in the same solution for $1 \mathrm{hr}$. Embryos younger than stage 18 were fixed by immersion only. After fixation, the embryos were transferred to $10 \%$ sucrose in $0.1 \mathrm{M}$ phosphate-buffered saline (PBS), $\mathrm{pH}$ 7.4, containing $0.05 \%$ sodium azide, for 15 to $18 \mathrm{hr}$ followed by $24 \mathrm{hr}$ in $0.1 \mathrm{M}$ PBS containing $20 \%$ sucrose. Embryos were then frozen in OCT embedding compound using isopentane (Baker) cooled with liquid nitrogen. Sections $10 \mu \mathrm{m}$ thick were cut on an Ames cryostat and mounted onto chrome-alum-coated slides. The sections were dried at room temperature and stored at $-20^{\circ} \mathrm{C}$ until processing with antisera.

To initiate the antibody staining, sections were treated for 5 min at room temperature with $0.3 \%$ Triton $X-100$ (Baker) in PBS, pH 7.4, containing $0.05 \%$ sodium azide (TBS). The sections were then exposed to $3 \%$ normal porcine serum in TBS for $15 \mathrm{~min}$ at room temperature, then they were washed three times in TBS. The sections were incubated overnight at either room temperature or $4^{\circ} \mathrm{C}$ with antisomatostatin serum (Accurate Chemical and Scientific Co.) at a dilution of 1:500 (unless otherwise indicated in the text) in $1 \%$ normal porcine serum in TBS. Both temperatures gave the same results. After three washes with TBS, sections were incubated for 30 min at room temperature in a 1:50 dilution of rhodamine conjugated to swine immunoglobulin directed against rabbit IgG (Accurate Chemical and Scientific Co.). The sections were then washed three times in TBS and coverslipped using glycerin/PBS $(3: 1, \mathrm{v} / \mathrm{v})$. The slides were inspected on a Zeiss standard microscope equipped for viewing rhodamine fluorescence. To determine the specificity of the observed immunofluorescence, control experiments included $(a)$ the use of normal rabbit serum in place of antisomatostatin serum and $(b)$ and the use 
of antisomatostatin serum in the presence of somatostatin 14 (Penninsula). For these latter adsorption experiments, a 1:500 dilution of antisomatostatin serum containing $0.2 \mathrm{mg} / \mathrm{ml}$ of the protease inhibitor aprotinin (Sigma) was prepared in $1 \%$ normal porcine serum in TBS. Somatostatin 14 (Penninsula) was then added to an aliquot of this solution to give a final concentration of $20 \mathrm{nmoles} / \mathrm{ml}$ and allowed to pre-incubate for $2 \mathrm{hr}$ at $4^{\circ} \mathrm{C}$. Following this pre-incubation the sections were processed for immunocytochemistry as described above for $18 \mathrm{hr}$ at $4^{\circ} \mathrm{C}$ using either antisomatostatin serum with or without added somatostatin. Sections exposed to either adsorbed serum or normal rabbit serum lacked specific immunoreactivity.

Dissection of sympathetic ganglia. To dissect the ganglia the embryos were first removed from the egg and placed on their dorsal surface in a $100-\mathrm{mm}$ Petri dish. The ventral body wall was opened using iridectomy scissors, and the embryos were eviscerated and cleaned of blood with Hanks' balanced salt solution buffered with $15 \mathrm{mM}$ HEPES to $\mathrm{pH}$ 7.4 (HBSS-HEPES). Lumbosacral paravertebral sympathetic ganglia were then dissected with tungsten needles, cut into pieces $2.5 \mathrm{~mm}$ long, and collected in a microhomogenizer embedded in dry ice.

Radioimmunoassay. The amount of immunoreactive somatostatin in undiluted and diluted samples of dissected sympathetic ganglia was determined by a well characterized radioimmunoassay (Patel and Reichlin, 1978). Following dissection, ganglia were homogenized in $200 \mu \mathrm{l}$ of $2 \mathrm{~N}$ acetic acid, and the homogenate was allowed to stand for $1 \mathrm{hr}$ at $4^{\circ} \mathrm{C}$ in a siliconized tube. The samples were then centrifuged at $7000 \times g$ and the supernatant removed and lyophilized. The lyophilized sample was stored at $-70^{\circ} \mathrm{C}$ until assay. The acetic acidinsoluble pellet was retained for protein determination by the method of Lowry et al. (1951). The radioimmunoassay standard curve was generated using somatostatin 14 (Peninsula). Monoiodinated l-tyrosine somatostatin (New England Nuclear) was the radioactive ligand. The standard curve and the amount of immunoreactive somatostatin in each sample were calculated using a computer-assisted least squares polynomial fit. The sensitivity of the assay was $2 \mathrm{pg}$ of somatostatin 14 per tube, and the antibody (from Dr. M. Root, Eli Lilly) was used at a final dilution of 1:30,000. This antibody showed $97 \%$ cross-reactivity with somatostatin 28 (Bachem) and less than $0.01 \%$ cross-reactivity with urotensin II, a peptide with some structural homology to somatostatin.

\section{Results}

Immunocytochemistry. Immunocytochemistry was used to determine when SLI can first be detected in the trunk region of quail embryos, since lumbosacral paravertebral ganglia cannot be dissected for radioimmunoassay analysis much prior to stage 23 . SLI was absent from the trunk region of stage $14\left(\mathrm{E} 2^{1 / 2}\right)$ and $17\left(\mathrm{E} 3^{1 / 2}\right)$ embryos, even when the primary antiserum was used at a dilution of 1:100. However, SLI was detectable at stage 18 (E4) using a 1:500 dilution of the primary antiserum. In these embryos, the SLI was observed in the primary sympathetic trunks on either side of the dorsal aorta (Fig. 1). The SLI was seen in the cytoplasm and was

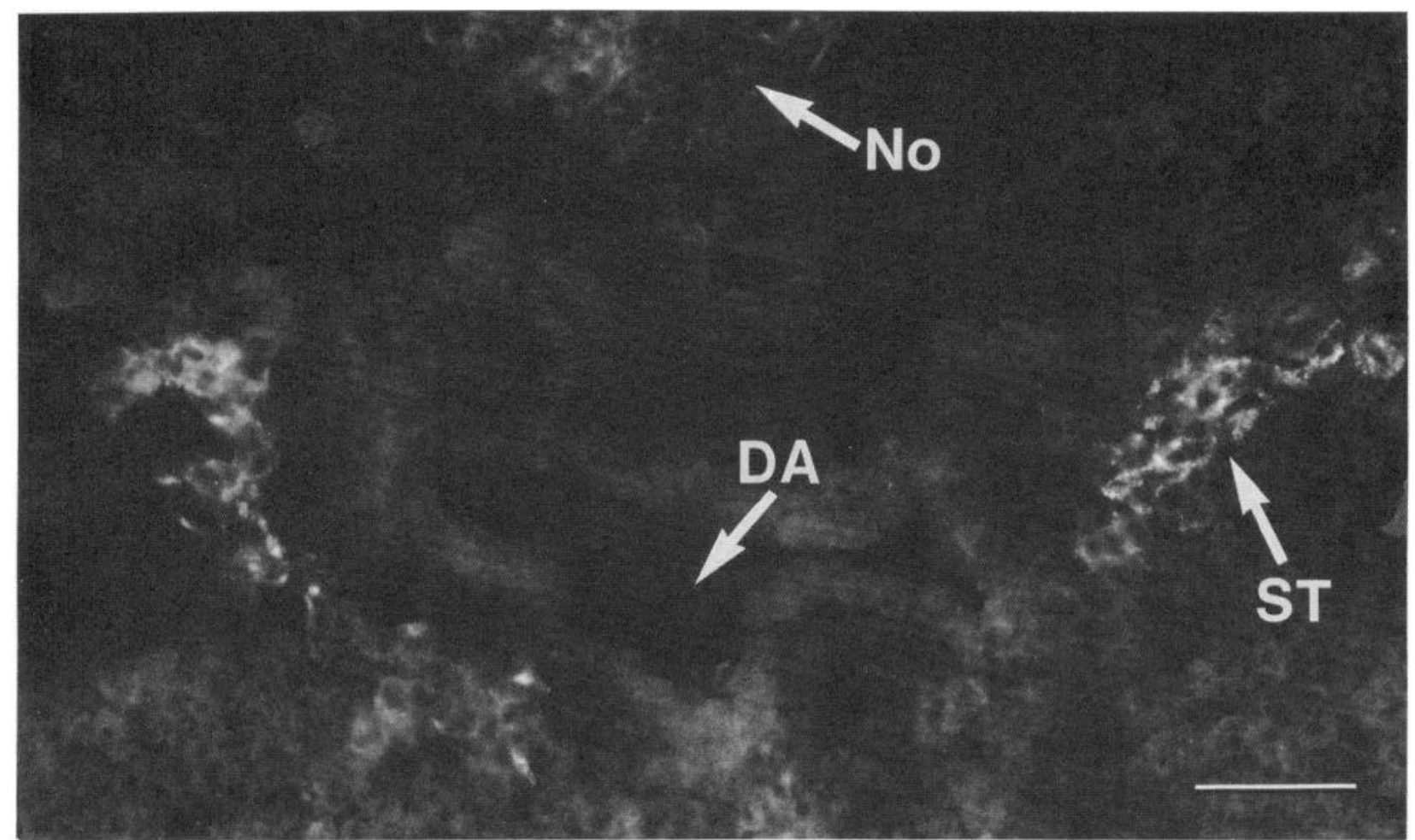

Figure 1. Onset of SLI in the primary sympathetic trunks. Photograph using rhodamine optics of a cryostat section from the trunk region of a stage 18 (E4) embryo processed to reveal SLI as described under "Materials and Methods." SLI can be seen in cells of the paired primary sympathetic trunks $(S T)$ which are located ventral and lateral to the notochord (No) and lateral to the dorsal aorta $(D A)$. The SLI is seen in the cytoplasm but is absent from the nucleus. Scale bar, $40 \mu \mathrm{m}$. 
absent from the nucleus. The primary sympathetic trunks are the initial sites of condensation of neural crest cells into sympathetic ganglia. Subsequently, some of the cells of the primary sympathetic trunk migrate dorsally to form the definitive paravertebral sympathetic ganglia. By stage $19\left(\mathrm{E} 4 \frac{1 / 2}{2}\right)$ the intensity of the immunofluorescence in the sympathetic trunks had increased, and some individual cells with SLI were seen near to, but displaced from, the main primary sympathetic trunks (Fig. 2A). These cells may have been migrating dorsally toward the definitive location of the sympathetic ganglia. The SLI was absent if the primary antiserum was pre-incubated in the presence of somatostatin 14 (Fig. 2B). At stage 19 the morphology of the immunoreactive cells is similar to that seen at stage 18 , with immunoreactivity present in the cytoplasm and absent from the nucleus (Fig. $2 C$ ). In stage 23 (E7) embryos a subpopulation of cells in the paravertebral sympathetic ganglia showed SLI, while many cells contained no detectable SLI (Fig. 3, $A$ and $B$ ). The SLI was located in cells that were adjacent to one another and that often occupied the ventral portion of the ganglion. At stage 27 (E10) SLI could still be detected in some cells in the ganglia, although the intensity of the immunofluorescence was diminished compared to stage 23 (E7) (Fig. 4, $A$ and $B$ ).

Radioimmunoassay. When radioimmunoassay was used to quantitate the amount of SLI present in sympathetic ganglia, we found that a substantial amount of SLI was present in ganglia removed at stage 23-24 (E78) (Fig. 5). The SLI content of the ganglia removed at stage 23-24 (E7-8) was much higher than that of ganglia removed at stage 26-27 (E9-10) or stage 31-32 (E13-14) (Fig. 5). The reduction in SLI content with development was $90 \%$ when the data were calculated on a per milligram of protein basis and $75 \%$ when they were calculated on a per ganglion basis (Fig. 5).

\section{Discussion}

Our results demonstrate that expression of SLI is an early event in the development of some cells in quail lumbosacral paravertebral sympathetic ganglia. SLI can be detected shortly after the first rudiments of the sympathetic ganglion form. In addition, there is a substantial decrease in SLI content during later stages of development at which other key maturational changes are occurring in these sympathetic ganglia.

Early sympathetic ganglion development and the appearance of SLI. Neural crest cells initially form on the dorsal portion of the neural tube and subsequently migrate along specific pathways in the embryo (Weston,
1970; Noden, 1978; Le Douarin, 1980). In the trunk region of the embryo there are two major migratory paths. One is a lateral path, below the ectoderm, and the other is a ventral path which is initially adjacent to the neural tube. Some of the neural crest cells which take the ventral path are the progenitors of the sympathetic ganglia (Weston, 1963; Le Douarin and Teillet, 1974; Thiery et al., 1982). The cells which give rise to the sympathetic ganglia first aggregate at $\mathrm{E} 3^{1 / 2}-\mathrm{E} 4$ to form a structure known as the primary sympathetic trunk (Kuntz, 1910). This structure is located lateral to the dorsal aorta. Expression of noradrenergic traits, including catecholamine content and immunoreactivity to synthetic enzymes in the catecholamine pathway, occurs shortly after neural crest cells reach this initial site of ganglion formation (Enemar et al., 1965; Kirby and Gilmore, 1976; Allan and Newgreen, 1977; Cochard et al., 1978; Teitelman et al., 1979). Catecholamine synthesis is probably not a postmitotic event in these cells, since DNA synthesis can be detected in cells that contain catecholamines and the catecholamine synthetic enzyme tyrosine hydroxylase (Cohen, 1974; Rothman et al., 1978, 1980).

We first detected SLI in the sympathetic trunk at stage 18 (E4), just after the stage at which catecholamines first appear. Thus, the onset of SLI in the lumbosacral sympathetic trunk is not any later than stage 18 (E4). Although we could not detect SLI prior to stage 18 , it is possible that some SLI is present but that the amount is below the threshold of detection of immunocytochemistry. Like catecholamine-containing cells, SLI-containing cells appear as small clusters of cells with a bilateral distribution lateral to the dorsal aorta (Fig. 1, Enemar et al., 1965; Kirby and Gilmore, 1976). Several groups have reported that such cell types as notochord and somitic mesenchyme and the molecule fibronectin, which are found in the vicinity of the developing sympathetic ganglia, can potentiate the expression of adrenergic traits in vitro (Cohen, 1972; Norr, 1973; Teillet et al., 1978; Fauquet et al., 1981; Sieber-Blum et al., 1981; Loring et al., 1982). The temporal and spatial proximity of SLI and catecholamine appearance in very young sympathetic ganglia raises the possibility that some of the same environmental cues may affect the regulation of both traits. Our present observations do not allow us to conclude that both catecholamines and SLI occur in the same cells in vivo. However, in tissue culture, some quail neural crest cells can develop and contain both catecholamines and SLI (Maxwell et al., 1983). In addition, the coexistence of the catecholamine synthetic enzyme dopamine $\beta$-hydroxylase and SLI has been dem-

Figure 2. SLI in a stage 19 (E41/2) embryo. A, Photographic montage using rhodamine optics of the dorsal region of a cryostat section from the trunk region of a stage 19 quail embryo processed to reveal SLI as described under "Materials and Methods." SLI is seen in the primary sympathetic trunks $(S T)$ with some SLI-positive cells in a more dorsal position evident (arrows). For purposes of orientation, the neural tube $(N T)$, notochord $(N o)$, dorsal root sensory ganglion $(D R G)$, dorsal aorta $(D A)$, and dorsoventral axis $(D V)$ are labeled. Scale bar, $50 \mu \mathrm{m}$. B, Adsorption control for SLI. Photograph taken with rhodamine optics of a cryostat section adjacent to the one shown in $A$ that was processed with antisomatostatin serum that had been pre-incubated in somatostatin-14 prior to its application to the section as described under "Materials and Methods." No SLI is observed. The notochord $\left(N_{O}\right)$ and dorsal aorta $(D A)$ are labeled for orientation. Scale bar, $50 \mu \mathrm{m}$. C, SLI-containing cells. Higher power photograph using rhodamine optics of SLI-containing cells in the primary sympathetic trunk of a stage 19 embryo. Scale bar, 20 $\mu \mathrm{m}$. 


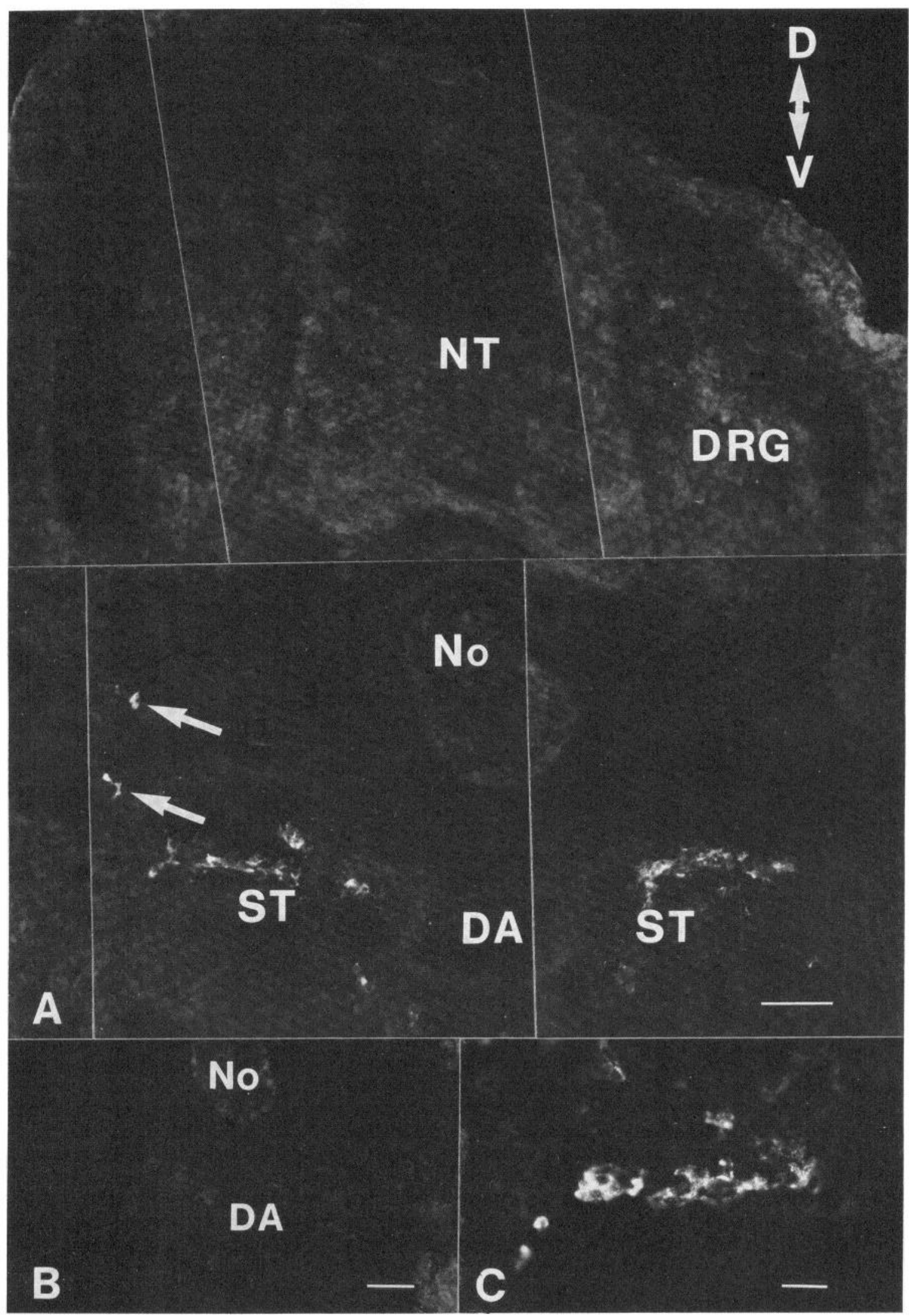

Figure 2 

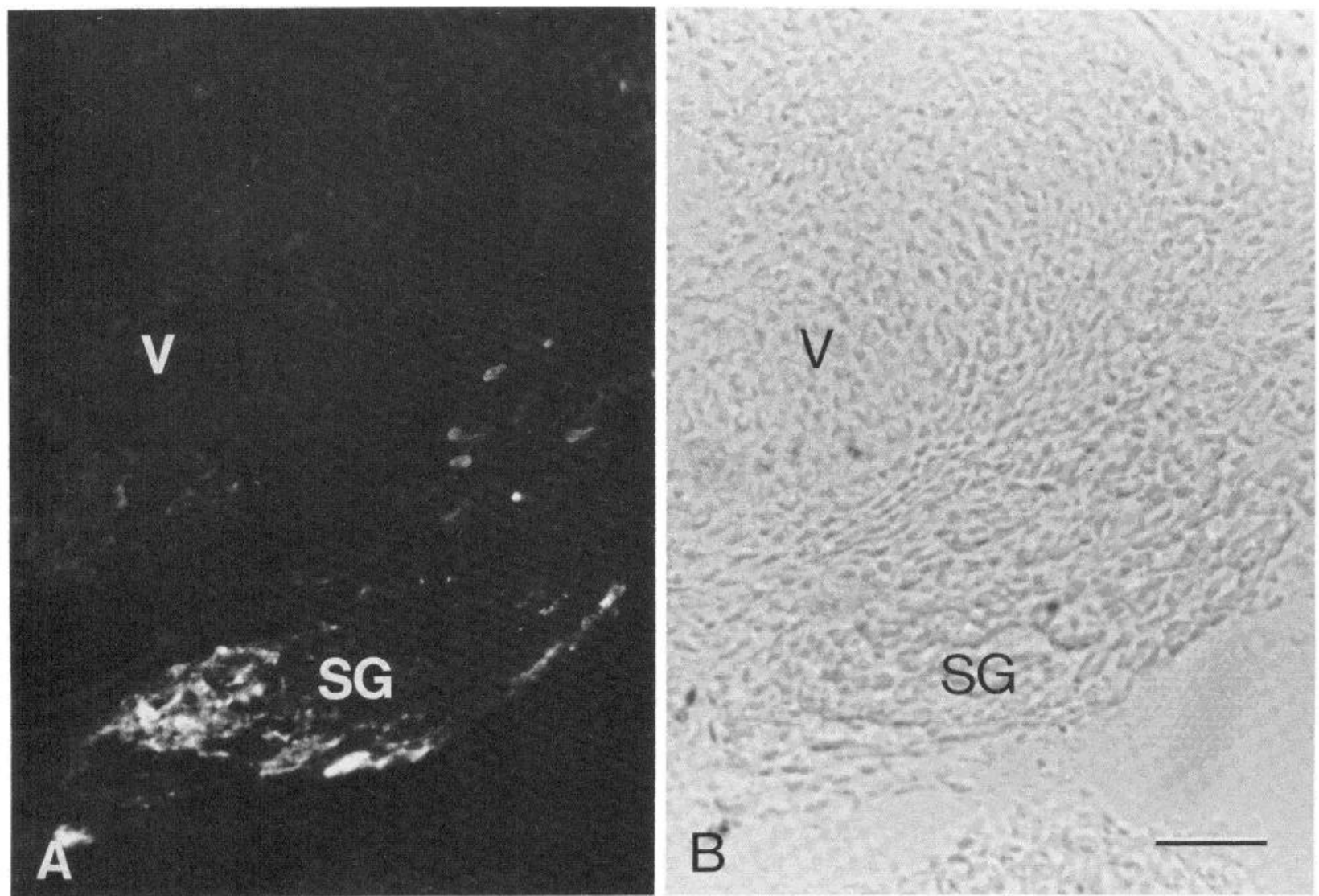

Figure 3. SLI in stage 23 (E7) sympathetic ganglia. A, Photograph using rhodamine optics of a cryostat section from a stage 23 embryo processed as described under "Materials and Methods." B, Photograph using phase contrast optics of the same field as in $A$. The vertebral cartilage $(V)$ and sympathetic ganglion $(S G)$ are labeled. Scale bar, $40 \mu \mathrm{m}$.

onstrated in some sympathetic neurons in vivo in the adult rat and guinea pig (Hökfelt et al., 1977).

Later sympathetic ganglion development and modulation of SLI content. Approximately 1 day after the formation of the primary sympathetic trunk, some cells separate from this primary trunk and migrate dorsally into the paravertebral region (Kuntz, 1910; Kirby and Gilmore, 1976). Formation of the definitive sympathetic ganglion occurs as a result of this dorsal cell migration. After the cells arrive at their definitive location, a number of significant developmental changes occur. Considerable cytological maturation occurs in the lumbosacral paravertebral sympathetic ganglia of chick embryos. At E7-8 neuroblasts with large dense core vesicles are prominent. By E10-12 these neuroblasts have increased in size and the large dense-core vesicles are seen in cellular processes, but they are no longer present in the cytoplasm of the cell body. By E13-15 small dense-core vesicles are observed in the neuroblast population. Some cells with very large dense-core vesicles are observed in the ganglion between E7 to E11, but they are not evident after E11 (Wechsler and Schmekel, 1967; Luckenbill-Edds and van Horn, 1980).

In addition to these cytological changes, evidence indicates that morphological synapses are present only after the sympathetic ganglia reach their definitive location. Most authors agree that in the lumbosacral paravertebral sympathetic ganglia of the chick, the first synapses are detected at E7-8 (Wechsler and Schmekel, 1967; Ross et al., 1978; Luckenbill-Edds and van Horn, 1980), although some workers report that they are not numerous until somewhat later (Hruschak et al., 1982). Taken together, these observations on synapse formation and cytological maturation indicate that considerable maturation occurs in the sympathetic ganglion cell population during E7 to E13. These changes probably occur as a result of a complex series of genetic, cellular, and hormone-mediated events (Landis and Patterson, 1981).

During this period of extensive sympathetic ganglion development, we have observed a dramatic decline in SLI content. Quail sympathetic ganglia from stage 2324, which corresponds to E8-9 in the chick, contain substantial amounts of SLI. During the next 2 days this SLI content drops precipitously. This decrease is due to an absolute decrement in SLI content in the ganglia, and not just to a relative increase of tissue that does not contain SLI. There are several ways this decrease might occur. One is that some cells may cease to contain SLI, but survive and express other phenotypic characteristics. Such a reduction in intracellular SLI content could be accomplished by several mechanisms, including decreased synthesis, increased catabolism, or increased release of SLI. A second alternative is that some cells which contain SLI may die. A third possibility is that the decrease in SLI content may be due to some modification of the molecular structure of the peptide in the 

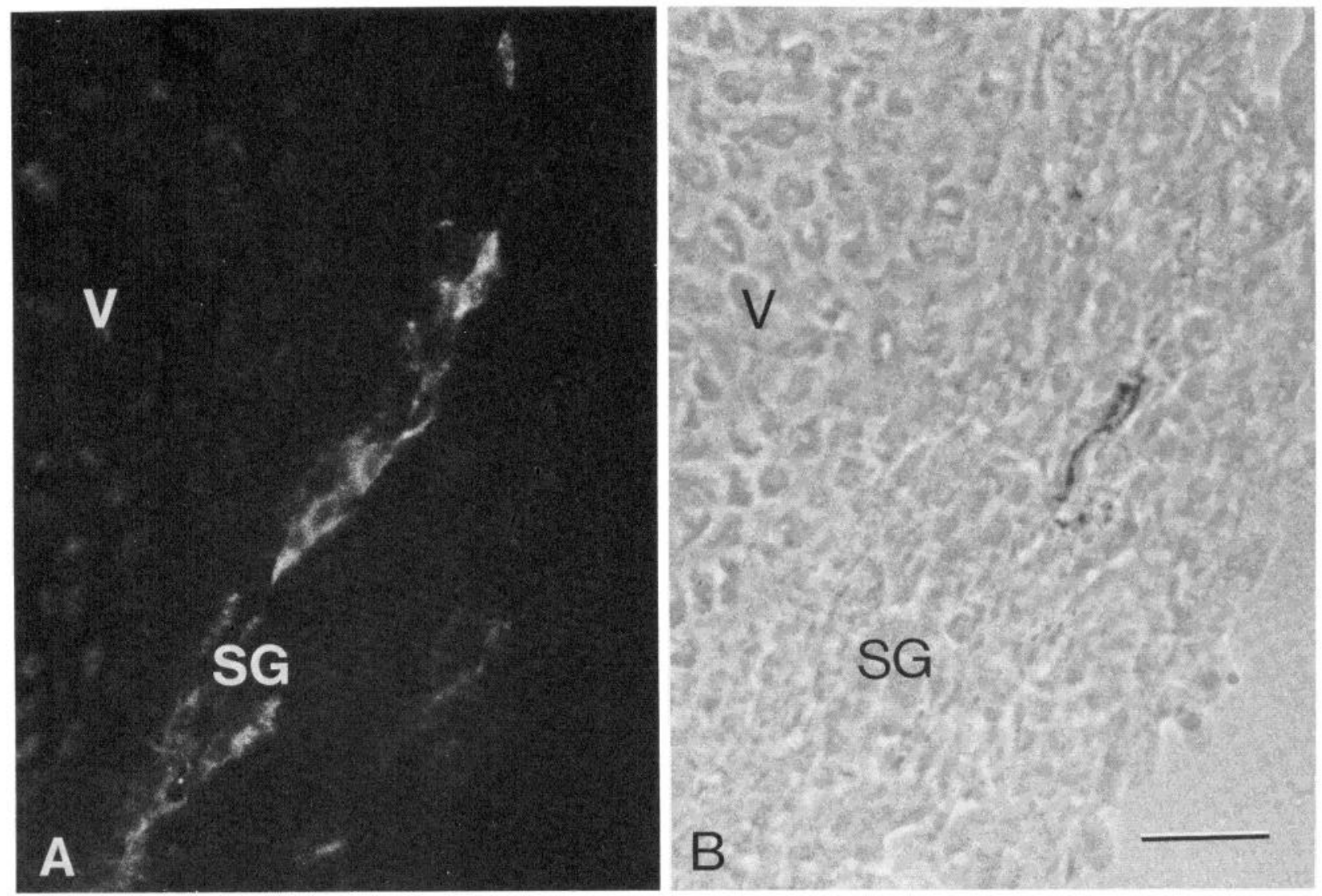

Figure 4. SLI in stage 27 (E10) sympathetic ganglia. A, Photograph using rhodamine optics of a cryostat section from a stage 27 embryo processed as described under "Materials and Methods." B, Photograph using phase contrast optics of the same field as in $A$. The vertebral cartilage $(V)$ and sympathetic ganglion $(S G)$ are indicated. Scale bar, $20 \mu \mathrm{m}$.

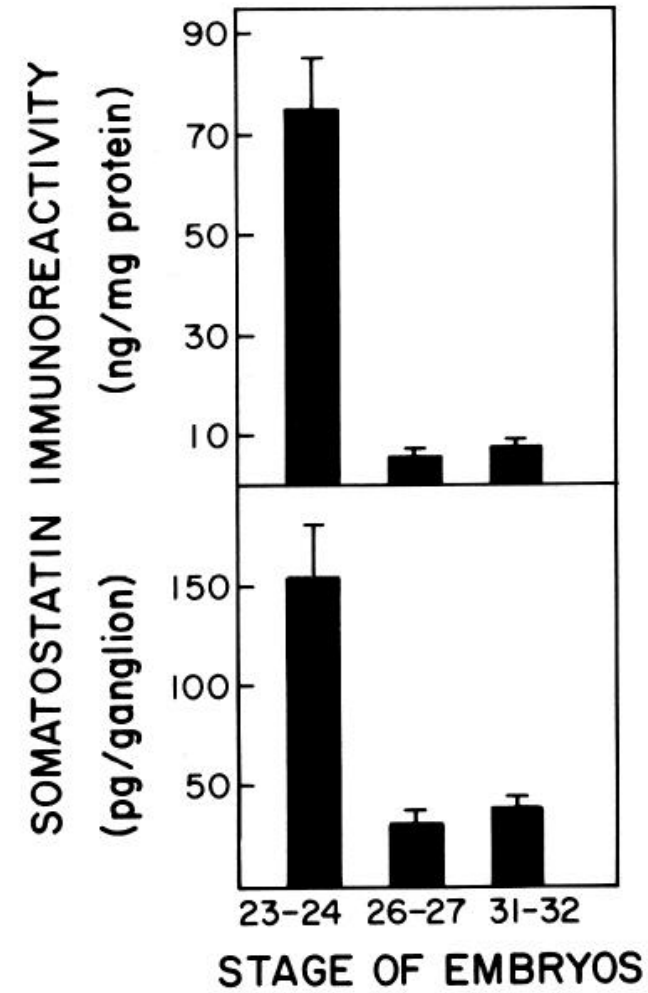

tissue that makes it undetectable by the antibodies we have used. A fourth possibility is that the reduction in SLI content in the ganglion is a reflection of increased transport of SLI from the cell bodies to processes and terminals that are excluded from our dissection.

Irrespective of the way in which the decline in SLI occurs, its temporal correlation with other developmental events in the ganglion is intriguing. The fact that the decline in SLI content occurs during the period when morphological synapse formation has been detected is consistent with observations that preganglionic nerve activity in vivo or membrane depolarization in vitro can reduce substance $\mathrm{P}$ and SLI content in developmentally older rat superior cervical ganglia (Kessler et al., 1981,

Figure 5. Quantitation of SLI in developing embryonic sympathetic ganglia. Lumbosacral paravertebral sympathetic ganglia were removed from the embryo at the stage indicated, and SLI was quantitated by radioimmunoassay as described under "Materials and Methods." Values are expressed as the mean \pm SEM with $N=7$ samples for stage 23-24 and $N=6$ samples for stage 26-27 and stage 31-32. Each individual sample contained 10 pieces of sympathetic ganglion trunks $2.5 \mathrm{~mm}$ long. The values for stage 23-24 differ from those for stage 26-27 with $p<0.0005$ (upper panel) and $p<0.002$ (lower panel) in the Student's $t$ test. 
1983a, b; Kessler and Black, 1982). The ability of quail neural crest cells to develop SLI in tissue culture (Maxwell et al., 1983) may allow us to test whether synapse formation and function play a role in the regulation of SLI content of young developing sympathetic neurons.

It would be of interest to learn if the modulation of SLI content in developing quail sympathetic ganglia is a quantitative phenomenon or whether there is truly transient expression of SLI by some cells. Shiosaka et al., (1981, 1982) have reported the transient appearance of SLI in cells of the developing central nervous system. The transient expression of some adrenergic characteristics has been detected in several systems, including the fetal rat gut (Cochard et al., 1978, 1979; Teitelman et al., 1978, 1979, 1981a; Jonakait et al., 1979, 1980; Gershon et al., 1982), fetal rat cranial sensory ganglia (Jonakait et al., 1982), fetal mouse pancreas (Teitelman et al., $1981 \mathrm{~b}$ ), and neonatal rat sympathetic ganglia which innervate the sweat glands of the footpads (Landis and Keefe, 1983). The significance of such transient, phenotypic expression is not currently understood; however, it appears to be a feature found in several developing tissues. Thus, it would be relevant to know if the change in SLI content we observe reflects transient SLI expression by some sympathetic neurons.

In conclusion, our findings provide evidence that the appearance of SLI is an early milestone in the development of some sympathetic neurons, and that SLI content declines dramatically during subsequent stages of development. It will be instructive to examine the mechanisms which control the initial and later expression of SLI in developing sympathetic neurons. In this regard, we would like to know how SLI expression is integrated with the appearance of other neuronal phenotypic characteristics. At present we do not know if the appearance of SLI in these ganglia is an early manifestation of a neurotransmitter or neuromodulator function for SLI or whether there might be a different function for SLI during development. Based on the apparently transient appearance of SLI in cells of the developing central nervous system, it has been hypothesized that SLI might play a trophic role in neural development (Shiosaka et al., 1981, 1982). Further experiments on the control of SLI expression in developing embryonic sympathetic ganglia may help to test this hypothesis.

\section{References}

Allan, I. J., and D. R. Newgreen (1977) Catecholamine accumulation in neural crest cells and the primary sympathetic chain. Am. J. Anat. 149: 413-421.

Chenard, P. H., and G. D. Maxwell (1983) Somatostatin immunoreactivity in embryonic sympathetic ganglia. Soc. Neurosci. Abstr. 9: 936.

Cochard, P., M. Goldstein, and I. B. Black (1978) Ontogenetic appearance and disappearance of tyrosine hydroxylase and catecholamines in the rat embryo. Proc. Natl. Acad. Sci. U. S. A. 75: 2986-2990.

Cochard, P., M. Goldstein, and I. B. Black (1979) Initial development of the noradrenergic phenotype in autonomic neuroblasts of the rat embryo in vivo. Dev. Biol. 71: 100-114.

Cohen, A. M. (1972) Factors directing the expression of sympathetic nerve traits in cells of neural crest origin. J. Exp. Zool. 179: 169-192.
Cohen, A. M. (1974) DNA synthesis and cell division in differentiating avian adrenergic neuroblasts. In Dynamics of Degeneration and Growth in Neurons, K. Fuxe, L. Olson, and Y. Zotterman, eds., pp. 359-370, Pergamon Press, Oxford.

Enemar, A., B. Falck, and R. Hakanson (1965) Observations on the appearance of norepinephrine in the sympathetic nervous system of the chick embryo. Dev. Biol. 11: 268-283.

Epstein, M. L., D. Sherman, and M. D. Gershon (1980) Development of serotonergic neurons in the chick duodenum. Dev. Biol. 77: 22-40.

Fauquet M., J. Smith, C. Ziller, and N. M. Le Douarin (1981) Differentiation of autonomic neuron precursors in vitro: Cholinergic and adrenergic traits in cultured neural crest cells. J. Neurosci. 1: 478-492.

Fontaine-Perus, J., M. Chanconie, J. M. Polak, and N. M. Le Douarin (1981) Origin and development of VIP and substance $\mathbf{P}$ containing neurons in the embryonic avian gut. Histochemistry 71: 313-323.

Fontaine-Perus, J. C., M. Chanconie, and N. M. Le Douarin (1982) Differentiation of peptidergic neurons in quail-chick chimaeric embryos. Cell Diff. 11: 183-193.

Gershon, M. D., T. P. Rothman, G. N. Teitelman, T. Joh, and D. Reis (1982) Incomplete expression of a catecholaminergic phenotype in cells that transiently appear during develop ment in the fetal rat gut. Soc. Neurosci. Abstr. 8: 189.

Hökfelt, T., L. G. Elfvin, R. Elde, M. Schultzberg, M. Goldstein, and R. Luft (1977) Occurrence of somatostatin-like immunoreactivity in some peripheral sympathetic noradrenergic neurons. Proc. Natl. Acad. Sci. U. S. A. 74: 3587-3591.

Hökfelt, T., O. Johansson, A. Ljungdahl, J. M. Lundberg, and M. Schultzberg (1980) Peptidergic neurones. Nature 284: 515-521.

Hruschak, K. A., V. L. Friedrich, Jr., and E. Giacobini (1982) Synaptogenesis in chick paravertebral sympathetic ganglia: A morphometric analysis. Dev. Brain Res. 4: 229-240.

Jonakait, G. M., J. Wolf, P. Cochard, M. Goldstein, and I. B. Black (1979) Selective loss of noradrenergic phenotype characters in neuroblasts of the rat embryo. Proc. Natl. Acad. Sci. U. S. A. 76: $4683-4686$.

Jonakait, G. M., M. C. Bohn, and I. B. Black (1980) Maternal glucocorticoid hormones influence neurotransmitter phenotypic expression in embryos. Science 210: 551-553.

Jonakait, G. M., K. A. Markey, M. Goldstein, and I. B. Black (1982) Transient expression of catecholaminergic traits in cranial nerve ganglia of the embryonic rat. Soc. Neurosci. Abstr. 8: 754.

Kessler, J. A., and I. B. Black (1980) Nerve growth factor stimulates the development of substance $P$ in sensory ganglia. Proc. Natl. Acad. Sci. U. S. A. 77: 649-652.

Kessler, J. A., and I. B. Black (1981) Similarities in the development of substance $\mathrm{P}$ and somatostatin in peripheral sensory neurons: effects of capsaicin and nerve growth factor. Proc. Natl. Acad. Sci. U. S. A. 78: 4644-4647.

Kessler, J. A., and I. B. Black (1982) Regulation of substance $\mathrm{P}$ in adult rat sympathetic ganglia. Brain Res. 234: 182-187.

Kessler, J. A., J. E. Adler, M. C. Bohn, and I. B. Black (1981) Substance $\mathrm{P}$ in principal sympathetic neurons: Regulation by impulse activity. Science $214: 335-336$.

Kessler, J. A., J. E. Adler, W. O. Bell, and I. B. Black (1983a) Substance $\mathrm{P}$ and somatostatin metabolism in sympathetic and special sensory ganglia in vitro. Neuroscience 9: 309318.

Kessler, J. A., W. O. Bell, and I. B. Black (1983b) Substance P levels differ in sympathetic target organ terminals and ganglion perikarya. Brain Res. 258: 144-146.

Kirby, M. L., and S. A. Gilmore (1976) A correlative histofluorescence and light microscopic study of the formation of the sympathetic trunks in chick embryos. Anat. Rec. 186: 
$437-450$.

Kuntz, A. (1910) The development of the sympathetic nervous system in birds. J. Comp. Neurol. 20: 283-308.

Landis, S. C., and D. Keefe (1983) Evidence for neurotransmitter plasticity in vivo: Developmental changes in properties of cholinergic sympathetic neurons. Dev. Biol. 98: 349372.

Landis, S. C., and P. H. Patterson (1981) Neural crest cell lineages. Trends Neurosci. 4: 172-175.

Le Douarin, N. M. (1980) Migration and differentiation of neural crest cells. Curr. Top. Dev. Biol. 16: 31-85.

Le Douarin, N. M., and M. -A. M. Teillet (1974) Experimental analysis of the migration and differentiation of neuroblasts of the autonomic nervous system and of neuroectodermal mesenchymal derivatives, using a biological cell marking technique. Dev. Biol. 41: 162-184.

Lewis, R. V., A. S. Stern, D. L. Kilpatrick, L. D. Gerber, J. R. Rossier, S. Stein, and S. Udenfriend (1981) Marked increases in large enkephalin-containing peptides in the rat adrenal gland following denervation. J. Neurosci. 1: 80-82.

Loring, J., B. Glimelius, and J. A. Weston (1982) Extracellular matrix materials influence quail neural crest differentiation in vitro. Dev. Biol. 90: 165-174.

Lowry, O. H., N. J. Rosebrough, A. L. Farr, and R. J. Randall (1951) Protein measurement with the Folin phenol reagent. J. Biol. Chem. 193: 265-275.

Luckenbill-Edds, L., and C. van Horn (1980) Development of chick paravertebral sympathetic ganglia. I. Fine structure and correlative histofluorescence of catecholaminergic cells. J. Comp. Neurol. 191: 65-76.

Lundberg, J. M., T. Hökfelt, A. Änggård, L. Terenius, R. Elde, K. Markey, M. Goldstein, and J. Kimmel (1982) Organizational principles in the peripheral sympathetic nervous system: Subdivision by coexisting peptides (somatostatin-, avian pancreatic polypeptide-, and vasoactive intestinal polypeptide-like immunoreactive materials). Proc. Natl. Acad. Sci. U. S. A. 79: 1303-1307.

Maxwell, G. D., P. D. Sietz, and S. Jean (1983) Expression of somatostatin immunoreactivity in neural crest cultures. Soc. Neurosci. Abstr. 9: 897.

Mudge, A. W. (1981) Effect of chemical environment on levels of substance $\mathbf{P}$ and somatostatin in cultured sensory neurones. Nature 292: 764-767.

Noden, D. M. (1978) Interactions directing the migration and cytodifferentiation of avian neural crest cells. In Specificity of Embryological Interactions, D. Garrod, ed., pp. 5-49, Chapman and Hall, London.

Norr, S. C. (1973) In vitro analysis of sympathetic neuron differentiation from chick neural crest cells. Dev. Biol. 34: $16-38$

Otten, U., M. Goedert, N. Mayer, and F. Lembeck (1980) Requirement of nerve growth factor for development of substance P-containing sensory neurones. Nature 287: 158-159.

Patel, Y. C., and S. Reichlin (1978) Somatostatin in hypothalamus, extrahypothalamic brain, and peripheral tissues of the rat. Endocrinology 102: 523-530.

Ross, L. L., L. Cosio, L. Witczak, and A. Smolen (1978) Synaptic development in the avian sympathetic ganglion. Anat. Rec. 190: 525 .

Rothman, T. P., M. D. Gershon, and H. Holtzer (1978) The relationship of cell division to the acquisition of adrenergic characteristics by developing sympathetic ganglion cell precursors. Dev. Biol. 65: 322-341.
Rothman, T. P., I. A. Specht, M. D. Gershon, T. H. Joh, F. Teitelman, V. M. Pickel, and D. J. Reis (1980) Catecholamine biosynthetic enzymes are expressed in replicating cells of the peripheral but not the central nervous system. Proc. Natl. Acad. Sci. U. S. A. 77: 6221-6225.

Saffrey, M. J., J. M. Polak, and G. Burnstock (1982) Distribution of vasoactive intestinal polypeptide-, substance P-, enkephalin- and neurotensin-like immunoreactive nerves in the chicken gut during development. Neuroscience 7: 279-293.

Shiosaka, S., K. Takatsuki, M. Sakanaka, S. Inagaki, H. Takagi, E. Senba, Y. Kawai, and M. Tohyama (1981) Ontogeny of somatostatin-containing neuron system of the rat: Immunohistochemical observations. I. Lower brainstem. J. Comp. Neurol. 203: 173-188.

Shiosaka, S., K. Takatsuki, M. Sakanaka, S. Inagaki, H. Takagi, E. Senba, Y. Kawai, H. Iida, H. Minagawa, Y. Hara, T. Matsuzaki, and M. Tohyama (1982) Ontogeny of somatostatin-containing neuron system of the rat: Immunohistochemical analysis. II. Forebrain and diencephalon. J. Comp. Neurol. 204: 211-224.

Sieber-Blum, M., F. Sieber, and K. M. Yamada (1981) Cellular fibronectin promotes adrenergic differentiation of quail neural crest cells in vitro. Exp. Cell Res. 133: 285-295.

Smith, J., P. Cochard, and N. M. Le Douarin (1977) Development of choline acetyltransferase and cholinesterase activities in enteric ganglia derived from presumptive adrenergic and cholinergic levels of the neural crest. Cell Diff. 6: 199216.

Teillet, M. -A., P. Cochard, and N. M. Le Douarin (1978) Relative roles of mesenchymal tissues and of the complex neural tube-notochord on the expression of adrenergic metabolism in neural crest cells. Zoon 6: 115-122.

Teitelman, G., T. H. Joh, and D. J. Reis (1978) Transient expression of a noradrenergic phenotype in cells of the rat embryonic gut. Brain Res. 158: 229-234.

Teitelman, G., H. Baker, T. H. Joh, and D. J. Reis (1979) Appearance of catecholamine-synthesizing enzymes during development of rat sympathetic nervous system: Possible role of tissue environment. Proc. Natl. Acad. Sci. U. S. A. 76: 509-513.

Teitelman, G., M. D. Gershon, T. P. Rothman, T. H. Joh, and D. J. Reis (1981a) Proliferation and distribution of cells that transiently express a catecholaminergic phenotype during development in mice and rats. Dev. Biol. 86: 348-355.

Teitelman, G., T. H. Joh, and D. J. Reis (1981b) Transformation of catecholaminergic precursors into glucagon (A) cells in the mouse embryonic pancreas. Proc. Natl. Acad. Sci. U. S. A. 78: 5225-5229.

Thiery, J. P., J. L. Duband, and A. Delouvee (1982) Pathways and mechanisms of avian trunk neural crest cell migration and localization. Dev. Biol. 93: 324-343.

Wechsler, W., and L. Schmekel (1967) Elektronenmikroskopische Untersuchung der Entwicklung der vegetativen (Grenzstrang-) und spinalen Ganglien bei Gallus domesticus. Acta Neuroveg. 30: 427-444.

Weston, J. A. (1963) A radioautographic analysis of the migration and localization of trunk neural crest cells in the chick. Dev. Biol. 6: 279-310.

Weston, J. A. (1970) The migration and differentiation of neural crest cells. Adv. Morphog. 8: 41-114.

Zacchei, A. M. (1961) Lo sviluppo embrionale della quaglia giapponese (Coturnix coturnix japonica T.e S). Arch. Ital. Anat. Embriol. 66: 36-62. 